\title{
Mellem guden og dyret
}

\section{En myteteoretisk læsning af Heinrich von Kleists Penthesilea i sammenligning med Euripides' Bak- kanterne og J.W. Goethes Iphigenie auf Tauris}

I den tyske åndshistorie findes der næppe et andet begreb - det skulle da lige være Ånden selv - så på én gang ombejlet, omstridt og udskældt som »der Mythos«. Holdningerne fordeler sig ud fra en gængs betragtning således, at en rationalistisk og humanistisk holdning, der i det mytiske ser en forældet religiøs resignation over for problemer der i en oplyst tid lader sig løse ved rationelle midler, står over for en irrationalistisk, sværmerisk position, der begræder oplysningens affortryllelse af verden og i myten ser den hybrid af kunst og umiddelbar religiøsitet, hvorved en genfortryllelse kan finde sted. Således bundet til skaren af irrationalistiske myte-tilhængere er myte-begrebet blevet genstand for en alvorlig miskreditering, idet man ikke har kunnet undgå at konstatere en vis kontinuitet i udviklingen fra de tidlige romantikeres remytologiseringsbevægelse - hvis mytebegreb måske slet ikke var så irrationalistisk endda - over Nietzsches påkaldelse af den tyske myte i Die Geburt der Tragödie, videre over det tidlige 20. århundredes kunstkultdyrkelse f.eks i kredsen omkring Stefan George og frem til mytebegrebets anvendelse i nazi-ideologisk sammenhæng som f.eks. i Alfred Rosenbergs Der Mythus des 20. Jahrhunderts.

Med hen- eller tilbageblik på Det tredje Rige har Mythos-begrebet ikke let kunnet frigøre sig fra associationen til barbari og propaganda. Inden for Frankfurterskolens kritiske teori er det således ofte blevet brugt som slet og ret synonymt med vold. I 70'erne er myten imidlertid igen blevet taget op til diskussion. Dette ikke mindst i Hans Blumenbergs Arbeit am Mythos og René Girards La violence et le sacré, der på hver sin måde indrømmer myten et par facetter mere end dem, der tilkom den inden for den ovennævnte oplysning-antioplysning-dualitet. Det er med afsæt i de myteteoretiske overvejelser, som frem for alt disse to teoretikere giver anledning til, at jeg i det følgende vil forsøge mig med en sammenligning af Heinrich von 
Kleists Penthesilea og Johann Wolfgang Goethes Iphigenie auf Tauris. Udgangspunktet er på den måde langt fra en forudsætningsløs tekstanalytisk beskæftigelse med værkerne, men snarere ønsket om at inddrage dem i en allerede igangværende teoretisk - og i grunden temmelig normativ - diskussion, som læsningen både kan bidrage til og selv nyde godt af.

Overordnet formuleret er bestræbelsen at tilføje Mythos-diskussionen en ekstra dimension: at supplere den dualistiske opstilling, således at den rationalistisk irreligiøse og den religiøst irrationalistiske pol sættes i perspektiv af en tredje, som man kunne kalde den dogmatiske pol. I modsætning til store dele af remytologiseringen kan den traditionelle mytiske praksis ikke uden videre afvises som et knæfald for en religiøs urerfaring. Den må - vil jeg i delvis tilslutning til Girard og delvis polemik mod Blumenberg hævde forstås som udspændt imellem denne erfaring og det dogmatiske forsøg på at forvalte den. I søsætningen af dette tredimensionelle mytebegreb, der har afgørende betydning for forståelsen af mytereceptionen i både Penthesilea og Iphigenie, vil et tredje drama, nemlig Euripides'BAKXAI (Bakkanterne), spille en væsentlig rolle. En rolle der i den større sammenhæng ikke bliver mindre væsentlig af, at Kleists tematisering af myteproblematikken i Penthesilea sker ved en genoptagelse af elementer fra netop denne klassiske tragedie.

\section{Mythos og Dogma}

Det ligger lige for at opfatte myten som en bearbejdelse af en oprindelig erfaring af afmagt over for omstcendigheden. Idet mennesket gør sig forestillinger om guddommelige magter og fortæller historier om dem, giver det virkelighedens konturløse overmagt en form, som gør det muligt at forholde sig mere myndigt til den: Ved at give et overvældende fænomen - det klassiske eksempel er lynnedslaget - en årsag, og dermed reducere det til et resultat af en mere egentlig, men også mere fjern agens, som man kan fortælle om, modereres gruen ved det umiddelbart nærværendes overmagt. Den omsættes i en anskuelig og plastisk billedlighed, som i den fortløbende myte-produktion til en vis grad lader sig manipulere efter behov. På den måde kan man med Hans Blumenberg opfatte myten som en distancering fra og overvindelse af en oprindelig »Absolutismus der Wirklichkeit«. ${ }^{1}$ I et opgør med enhver religionsfilosofisk sværmen om urafmagtens sakrale »Terror«, »den dæmoniske fortryllelses passivitet», bestemmer Blumenberg myten som »Poesie«, som »fantasiens udsvævelse i den antropomorfe tileg-

1. Hans Blumenberg: Arbeit am Mythos, Frankfurt a. M. 1979, p. 10 (herefter $A M$ ). 
nelse af verden « ${ }^{2}$. I den billedskabende fantasis »Arbeit der Mythos«, der fortsættes i mytereceptionens "Arbeit am Mythos«, ligger således et afgørende frigørelsespotentiale, som den polyteistiske gudeverdens heterogenitet for Blumenberg er et udtryk for: »Myten«, skriver han, »har udført sin nedbrydelse af 'virkelighedens absolutisme' ved hjælp af en fordeling af den opake blok af mægtighed, som mennesket står overfor, på flere magter, der indbyrdes intrigerer imod og ophæver hinanden« ( $A M$, p. 20). Polyteismen fordeler omstændighedens overmagt på flere guddommelige figurer, og gør den dermed mindre overvældende. Når eksempelvis krigslykkens omslag i Iliaden iscenesættes som udslag af gudernes indbyrdes intrigeren på kryds og tværs, udfoldes således ifølge Blumenberg en gudsbilledlighed, der ikke lægger op til gudsfrygtig kasten sig på knæ, men snarere til trækken på skuldre og smilebånd, »en munterhed, der ikke står i noget forhold til konsekvenserne for trojanere og grækere på krigsskuepladsen« $(A M$, p. 25).

Blumenberg vender sit Mythos-begreb polemisk imod det, han kalder Dogma, dvs. den monoteistiske traditions forsøg på ved indførelsen af et billedforbud at knægte mytens poetiske frihed eller at reducere religionens indhold til et antal abstrakte læresætninger (»Du må kun have én Gud«, »Du må ikke lave billeder", "Gud har kun inkarneret sig én gang“, „Kristi nærvær kan kun reaktualiseres i nadveren« osv.). Ifølge Blumenberg sker den jødiske og kristne dogmatiks begrænsning af mytens udfoldelse med den bevidste hensigt at opretholde den oprindelige Terror som et middel til kirkelig magtudøvelse: »Billedforbudet kender til den affortryllende og frigørende kraft, som ligger i den mytiske omgang med gudenavnene, gudebillederne og gudefortællingerne. $\star^{3}$ Den monoteistiske tradition kan imidlertid på sin side motivere sit billedforbud under henvisning til egenskaber ved mytens billedlighed, som Blumenberg vælger at se hen over. Den bibelske Dogma tager nemlig ikke udgangspunkt i gudsbilledlighedens distancerende, men derimod i dens aktualiserende potentiale. Som det f.eks fremgår af historien om guldkalven i Anden Mosebog udspringer billedforbudet ikke primært af frygten for, at mennesket med sin billedskabelse skal løsrive sig fra »den dæmoniske forryllelses passivitet«, men omvendt af frygten for at dyreguden skal inkarnere sig i billedet - med andre ord: at billedet skal overmande med sin sakrale aura og dermed netop aktualisere den dæmoniske fortryllelse. På baggrund af jødedommens generelle insisteren på den ene Guds absolutte transcendens, på at Gud kun i form af Torah’ens etiske fordring

2. Hans Blumenberg: "Wirklichkeitsbegriff und Wirkungspotential des Mythos«, in Manfred Fuhrmann (red): Terror und Spiel, München 1971, p. 13.

3. Op. cit., p. 19. 
træder i forhold til mennesket, må enhver guddommelig inkarnation betragtes som dæmonisk og den ekstatiske effekt den medfører som en vildfarelse. ${ }^{4}$

Mytens aktualiserende potentiale spiller ligeledes en vigtig rolle for myteforståelsen hos teologen Wolfhart Pannenberg. Ifølge Pannenberg er religiøse fortællinger mytiske i det omfang, de indebærer forestillingen om guddommelige og for menneskets aktuelle verden konstituerende urhandlinger - urhandlinger som i den kultiske mimesis aktualiseres, for at mennesket kan tage del i dem og således så at sige blive ét med sin verden. Det særlige ved den gammeltestamentlige religiøsitet er, at man i kraft af syndefaldsberetningen forestiller sig mennesket som fundamentalt adskilt fra Guds verdenskonstituerende handling, Skabelsen: »Dermed«, skriver Pannenberg, »har man mistet den væsentlige egenskab ved myten, at den oprindelige begivenhed samtidig til enhver tid kan blive præsent i den kultiske højtidelighed. $\ll^{5}$ Jødedommen nægter sig altså den kultiske bejaelse af verdensomstændigheden, som myten med sit aktualiseringspotentiale giver anledning til. At pagten med Gud sluttes uden dennes nærvær, afspejler substansens karakter af uendelig etisk fordring - det evige eksil - og ikke en ekstatisk bliven ét med hans skaberværk. På baggrund af denne for jødedommen fundamentale uvilje over for mytens verdensbejaende egenskaber er det ikke overraskende kontroversielt, når kristendommen med Kristus genindfører forestillingen om Guds nærvær, erklærer at verden er givet på ny og etablerer den kristne kult som muligheden for at deltage i denne ny verdenskonstitution. ${ }^{6}$

Nu skal det imidlertid ikke dreje sig om kristendommens ganske særlige sammensmeltning af jødisk billedforbud og "ny myte«. Redegørelsen her tjener primært opstillingen af et mytebegreb, der både, som Blumenbergs, tager højde for mytens distancerende egenskaber og, som det jødiske billedforbud, for dens aktualiserende potentiale. Myten, menneskets billedlige bearbejdelse af omstændighedserfaringen - det være sig erfaringen af psykiske omstændigheder som drifter, lidenskab og affekt, vold, ${ }^{7}$ ydre natur-

4. I et essay med titlen "Aimer la Thora plus que Dieu«motiverer Emmanuel Lévinas således den jødiske skrift-religion, som »en beskyttelse imod vanviddet i en umiddelbar kontakt til det sakrale«. »Forholdet imellem Gud og menneskene« hedder det endvidere, »er ikke nogen sentimental forening i en inkarneret guds kærlighed, men en forbindelse imellem ånder formidlet igennem en lære, Torah'en. Det er netop ved sin tale og ikke ved inkarnationen, at Gud lever iblandt os", Difficile Liberté, Paris 1963, p. 204.

5. Wolfhart Pannenberg: "Späthorizonte des Mythos in biblischer und christlicher Überlieferung«, in Manfred Fuhrmann (red): Terror und Spiel, München 1971, p. 503.

6. "At dø og genopstå med Kristus, " skriver Pannenberg, "det har siden Paulus været ledemotivet i kristendommens selvforståelse«, op. cit., p. 518. I forhold til de hedenske ritualer, som Pannenberg sammenligner med, kan den kristne kults deltagelse i guden dog menes at have en særlig karakter, da der på én gang synes at være tale om en gåen op i verden og i udfrielsen fra verden. 
fænomener, sygdomme, døden eller tilfældet - skal altså her forstås som et fænomen, der svinger imellem den poetiske udsvævelses opløsning af urafmagten og idoldyrkelsens aktualisering af en ny afmagt i den sakrale nærværserfaring. I den monoteistiske tradition opfattes det som forfængeligt hovmod, når mennesket bilder sig ind at kunne kontrollere gudsbilledlighedens magt. Derfor forsøger den med dogmatikken at stille mytens idolatri til regnskab over for en ubilledlig gudelære, enten ved, som i jødedommen, at forbyde billeder, eller, som i den kristne tradition, at dyrke billedligheden inden for ganske bestemte kirkelige rammer. Spørgsmålet er imidlertid, om ikke den hedenske mytedyrkelse selv indebærer samme dobbelthed af gudsbillede og gudelære. Det mytiske, som vi f.eks møder det i den græske tragedie, er nemlig hverken blot poetisk udsvævelse eller dæmonisk besættelse, den er også kulturindstiftende og tjener således opretholdelsen af en vis religiøs orden. Dette synes at have gjort det nødvendigt at regulere den konkrete digtning med og dyrkelse af gudebilleder under henvisning til et referenceniveau: gudelæren. Denne idé vil jeg kort illustrere ved et kig på Euripides' Bakkanterne.

\section{Mytens dogmatiske selvregulering}

I Bakkanterne skildres det, hvorledes Dionysos kommer til Theben og udløser en række af de entusiastiske ritualhandlinger, vi normalt betegner som dionysiske. Koret fortæller myten om Dionysos: om Semeles nedkomst med Zeus' søn og hendes død ved synet af tordengudens mægtighed, om hvorledes Zeus gemmer Dionysos i sit lår, for at beskytte han over for Heras vrede, om Dionysos' anden fødsel og hans vandring fra Asien ind i Grækenland med mænadehoben efter sig. Den rituelle fejring af Dionysos forholder sig mimetisk til denne myte. Som det hedder i Niels Møllers oversættelse: "tyrehornsguden Gud har født, / kransed hans hoved med slanger, / og derfor de vilddyr mainaderne jager og bær i krans / slangerne. $\ll^{8}$ Tilsvarende

7. I La violence et le sacré bestemmer René Girard den sakrale omstændighed som en slags urvold, dvs. den sum af mellemmenneskelig aggression, som ethvert samfund må konfrontere i forsøget på at etablere en fredelig sameksistens: "Det sakrale er altså blandt andet, men først i anden række, uvejr, skovbrænde, epidemier, der undertvinger en hel befolkning. Frem for alt, om end på tilsløret vis, er det menneskenes egen vold, der fremstår som noget ydre $\mathrm{i}$ forhold til mennesket og fra tid til anden jævnføres med de andre kræfter, som udefra indvirker på det. Det er er denne vold, der udgør det sakrales hjerte og hemmelige sjæl, "La violence et le sacré, Paris 1972, p. 52. Mytens opståen og den dermed forbundne kultiske praksis forklarer Girard, hvilket jeg skal vende tilbage til, ud fra kulturens behov for at foretage en rituel udstødelse af denne urvold.

8. Euripides: Bakchanter, oversat af Niels Møller, København 1931, v. 103 ff (herefter BA). Frem for den nyeste danske oversættelse foretrækker jeg at citere fra denne ældre version. 
bærer de entusiastiske kvinder thyrsos, hjorteskind, og vedbend (der ligner vinløv) for i dansen at blive ét med guden og hans gaver: »han, der os gav: / brusende dans i flok, / latter ved fløjtespil, / lise mod sorgerne, / når druen funkler / ved hellige fester, / når vinen gyder / ved vårligt samlag, som vedbend pryder, / blund over mænd« $(B A$, v. 365 ff.). Myte og kult synes altså her at samvirke på en måde, der minder om den, jeg har skitseret ovenfor: En omstændighed, visse menneskelige lidenskaber, der truer med at nedbryde skellet imellem det menneskelige og det dyriske, udlægges i myten fortællingen om Dionysos som dansens, rusens og frugbarhedens gud - som et udtryk for en guddommelig handling, og denne handling aktualiseres mimetisk i kulten, for at mennesket kan bejae og tage del i den almægtige omstændighed. Thebanerinderne går vidt i hengivelsen til den rituelle mimesis, og processen, der udvisker grænsen imellem gud, menneske og dyr, ender med, at Thebens konge Pentheus sønderflås af sin moder Agaue, ligesom Dionysos i urtiden sønderflåedes af titanerne.

Præsentationen af disse udskejelser som guddommeligt legitimeret praksis udgør imidlertid kun ét niveau i teksten. Dramaet som helhed kaster et ganske andet lys over den dionysiske entusiasme og dermed også på den ikke mindre entusiastiske reception, den hos Nietzsche og andre er blevet genstand for. Når Dionysos iværksætter det dionysiske vanvid, er det nemlig for at straffe befolkningen i Theben, frem for alt Semeles søstre, der har benægtet, at Dionysos skulle være søn af Zeus og derfor forsømt at dyrke ham på passende vis: »Nu«, forklarer Dionysos, »har min brod dem drevet ud af hus og bo / i rus - de går på bjærget, rykt fra sind og sans, / redt til, som jeg dem tvang, i mine sværmes dragt. / [...] denne by skal lære (selv om den ej vil), / at den er uindviet i min helligfærd, / og min moders ry jeg værger, så enhver på jord / kan se: det var en guddom, som hun fødte Zeus« ( $B A$, v. 31 ff). Thebanernes religiøse ekstase er altså ikke i samklang med gudens vilje, men netop udtryk for deres uindviethed. Dramaet installerer således en teologisk instans, hvorudfra der udtales et korrektiv til den konkrete mytisk-rituelle praksis, som dramaet skildrer, og som angiveligt afspejler en religiøs tendens, der var omsiggribende på Euripides' tid. ${ }^{9}$ Euripides synes, som Bernhard Böschenstein har bemærket, wat relativere og afgrænse dramaet ud fra gudens fixpunkt. «10 Hvad den overleverede gudsbilledlighed siger, er ét, hvad guden fordrer, er noget andet.

9. Ifølge E.R. Dodds var dette tilfældet, dog ikke nødvendigvis i form af en konkret dyrkelse af Dionysos: „I Athen var Dionysos blevet tæmmet; men deraf følger ikke, at det dionysiske sindelag var forsvundet, og der er faktisk mange beviser på, at religion af den orgiastiske type i tiden omkring den peloponesiske krig - formentlig på grund af de sociale spændinger den førte med sig - igen begyndte at dukke op under andre navne." Dodds refererer således til dyrkelsen af „de øster- og nordlandske mysterieguder, Cybele, Bendis, Attis, Adonis, og Sabazius«, »Euripides’ Bacchae: Introduction«, Oxford 1944, p. XX. 
Det, Dionysos i Euripides drama fordrer, er sin plads i gudekollektivet. Hævdelsen af hans gudestatus sker ikke blot ved den ellers overbevisende demonstration af hans numinøse magt, men gennemgående under henvisning til Zeus, som gudehierarkiets overordnede. "Zeus selv gav længst sit minde til, hvad her er sket«, hedder det hen mod slutningen ( $B A$, v. 1351). Som korrektiv til bakkanterne, der i ekstasen synes at opfyldes af den ene nærværende gud, kræver Dionysos altså sin særlige plads i den samlede dyrkelse af de olympiske guder. Dette er interessant at bemærke i forbindelse med Hans Blumenbergs myteteori, og dens vægtning af mytens fordeling af den guddommelige almagt på flere gudeskikkelser. Her - må vi konstatere sikres magtdelingen ikke, som i Blumenbergs teori, af gudsbilledlighedens frihed, men derimod af en slags polyteistisk dogmatik, som med belærende ord netop begrænser billedlighedens udfoldelse. Foruden at være straffende, er Euripides' Dionysos - måske alligevel ikke aldeles væsensforskelligt fra jødernes Jahve - frem for alt en talende, og med sin tale fordrende gud: »Så siger jeg: af ingen jordisk fader født, / Dionysos, Zeus's søn. Og hvis I havde vidst, - / hvad ej I vilde, - klog i hu at hylde mig, / da blev jeg eders hjælper, da vandt lykken $I$ « $(B A$, v. 1342 ff.).

Læsningen af Bakkanterne giver således anledning til at forestille sig, at myten, der som billedlig forarbejdning af omstændighedens magt bevæger sig imellem den distancerende og den aktualiserende relation til denne magt, netop for at finde den rette balance imellem disse to yderligheder må supplere sin billedlighed med en regulativ gudelære. Dyrkelsen af gudebilledet stilles til regnskab over for dets referent, guden. I kraft af dette dogmatiske element kan de religiøse energier forvaltes på en måde, der er hensigtsmæssig for kulturen som helhed, f.eks ved at afgrænse tid og sted for den rituelle aktualisering. Denne selvregulerende mekanisme har væsentlige ligheder med grundfiguren i René Girards forståelse af forholdet imellem myte og ritual. Den omstændighed, Girards spekulativt antropologiske teori $^{11}$ tager udgangspunkt i, er som anført kulturens »immanente vold«, denne rest af aggression, som samfundet ikke kan tackle med civiliserede midler og derfor må forholde sig religiøst til. Det er således urvolden, som myterne fortæller om, og som i den rituelle praksis gøres til genstand for en symbolsk uddrivelse. Den rituelle proces må ifølge Girard gennemløbe to stadier for at have den hensigtsmæssige katarsis-funktion: Først må volden

10. Bernhard Böschenstein: "Die Bakchen des Euripides in der Umgestaltung Hölderlins und Kleists«, in Stanley A. Corngold et. al (red): Aspekte der Goethezeit, Göttingen 1977, p. 250 .

11. Det følgende er skrevet specifikt med henblik på La violence et le sacré. Jeg ser således i denne sammenhæng bort fra den kristne overbygning til myteteorien, som Girard har udfoldet i en række andre værker. 
aktualiseres i sin mest radikale form, hvilket giver sig udtryk i en tilstand af total forskelsløshed, hvor alle tabuer brydes, alle grænser overskrides grænserne imellem dit og mit, som det sker i forbrydelsen og grænserne imellem gud, menneske og dyr, som i den religiøse ekstase. Dernæst må ondet uddrives. Dette sker ved at volden, der indtil omslaget har gjort sig gældende i et kaotisk alle mod alle - det som Girard kalder »dialogisk vold«med en mirakuløs samstemmighed rettes imod ét individ, en syndebuk, som så ofres.

Afgørende i vores sammenhæng er det nu, at Girard bestemmer mytens vigtigste funktion som netop udpegelsen af syndebukken og således heri ser selve muligheden for en genoprettelse af de kulturelle forskelle hinsides ritualets aktualisering af forskelsløsheden. ${ }^{12}$ Det er myten, der, idet den installerer en guddommelig instans, hvorudfra ofret fordres, dirigerer volden i den retning, der er nødvendig for en genoprettelse af de kulturelle orden. Som Girard selv påpeger, genfindes netop dette rituelle forløbs to stadier i Bakkanterne, først mænadernes ekstatiske hengivelse til forskelsløsheden, siden mytens ny forskelssættelse i kraft af Dionysos' dom over Pentheus, Agave og Kadmos: „Efter at han har forårsaget Pentheus' død, jager guden resten af familiemedlemmerne ud af byen. Fred og orden kan vende tilbage til Theben, der fra nu af vil ære den nye guddom, sådan som han forlanger. Mordet fremtræder på en gang som frugten af en guddommelig handling og som en spontan frigørelse. Gudshandlingen udspiller sig i ofringens allerede ritualiserede rammer. Guden selv spiller rollen som den ofrende. ${ }^{13}$ I takt med at offeret for volden indskrænkes til at være syndebukken, indskrænkes dens agent altså til at være guden. Myten gennemfører på den måde omslaget fra den dialogiske vold, der gør sig gældende imellem menneskene til gudens transcendente vold. Skellet imellem det højeste og det laveste, imellem guden og dyret, genindstiftes. „Det religiøse«, skriver Girard, »er således på ingen måde »unyttigt«. Det umenneskeliggør volden, det unddrager mennesket dets vold for at beskytte det over for den og omskaber den til denne transcendensens altid præsente trussel, som fordrer formildelse ved hjælp af egnede riter såvel som ved beskeden og forsigtig opførsel« $(V S$, p. 191). Der er tale om en dramatisk vekselvirkning, hvor indsættelsen af den transcen-

12. Det er måske nødvendigt her at kommentere det ofte diskuterede spørgsmål, om myten går forud for ritualet eller omvendt. Hidtil har jeg formuleret det således, at ritualet arbejder med mytens billedlighed. Her hos Girard vendes nu rækkefølgen om, således at myten giver form til ritualets vold. Det afgørende er imidlertid, at vekselvirkningen og rækkefølgen hos Girard netop tjener til at tydeliggøre, at mytens billedproduktion nok er forudsætningen for ritualets mimesis, men at myten herefter igen bliver relevant, nemlig som referent, og i denne egenskab virker tilbage på den rituelle aktualisering, som den selv har leveret materialet til.

13. René Girard: La violence et le sacré, Paris 1972, p. 185 (herefter VS). 
dente magt er forudsætningen for, at den rituelle opløsning når sit katarsiske mål, men ritualets aktualisering af den absolutte forskelsløshed er samtidig forudsætningen for, at mytens ny orden kan bære frugt: „For at orden igen kan indfinde sig, må den kaotiske tilstand først nå sit højdepunkt; for at myterne igen kan finde form, må de først falde helt fra hinanden« (VS, p. 118).

I Girards teori og Euripides' drama kan den hedenske mytes indebyrd altså hverken reduceres til den rene nærværsreligiøsitet, sådan som det kan synes forudsat i det jødiske billedforbud, eller, som i Blumenbergs opfattelse, til fantasiens distancerende spil. Hverken til sakral terror eller poetisk udsvævelse. I kraft af sit dogmatiske element indtager myten derimod en regulerende funktion i forhold til den ekstatiske nærværserfaring, der aktualiseres i ritualet. $\mathrm{Nu}$ ville det ganske vist være overilet at hævde, at Girards teori og mytens dogmatiske selvregulering er repræsentativ for den oldgræske religiøsitet som sådan, endsige at fremhævelsen af denne figur i $B a k$ kanterne yder det mangefacetterede værk fuld retfærdighed. ${ }^{14}$ Inddragelsen af Euripides' drama skal i denne sammenhæng først og fremmest eksemplificere, hvorledes mytens dogmatiske selvregulering i givet fald måtte fungere. Når denne idé interresserer, er det hverken i kraft af dens oldtidshistoriske forklaringspotentiale eller dens eventuelle værdi for Euripideseksegesen, men på grund af dens tematiske relevans for læsningen af Kleists Penthesilea og Goethes Iphigenie auf Tauris. Til trods for at vi hermed tager et spring på omkring 2200 år frem i tiden, henover mange århundreders kristen dominans, og ind i den moderne tids affortryllede verden, hvor betydningen af myte og ritual måtte menes at være indskrænket til den private overtros sfære, er det græske mytestof på de to dramaers tilblivelsestid stadig levende i litteraturen. Dette kan slet og ret opfattes som et udslag af en klassicistisk dannelsestraditions påbud, men også - som jeg her vil gøre det, - som udtryk for en stadig litterær beskæftigelse med religionsfilosofiske problemstillinger, som netop mytereceptionen giver mulighed for at sætte i scene.

14. At Girards vigtigste materiale udgøres af Bakkanterne og andre græske tragedier betyder i øvrigt ikke, at han uden videre identificerer tragedien med det offerrituelle forløb, som han fremanalyser. Tværtom: Når tragedierne kan bruges til at tematisere dette forløb, er det ifølge Girard i kraft af et skarpsyn i tragedierne, som netop vidner om, at troen på processen selv er gået tabt. Tragedien som værk køber ikke den mytiske udpegelse af syndebukken, som tilsyneladende fungerer inden for rammerne af dens handlingsforløb. Den afslører den derimod og er således udtryk for offerkultens krise på tærsklen til den græske civilisation. 


\section{Humanisering af myten i Iphigenie}

I Goethe-receptionen betragtes Iphigenie auf Tauris (endelig udgave 1787) gennemgående, ikke mindst i kraft af Wolfdietrich Raschs kanoniske Goethes »Iphigenie auf Tauris" als Drama der Autonomie, ${ }^{15}$ som et udtryk for oplysningenstidens emancipationsidealer. Dramaet placerer Iphigenie i konflikten imellem hensynet til taurernes tillidsfulde kong Thoas og broderen Orestes' planer om at bortføre hende fra øen og lader i denne situation hendes autonome valg af den ærlige appel om Thoas nåde fremstå som den eneste vej ud af en uendelig kæde af voldshandlinger. Denne overvindelse af volden hænger sammen med værkets såkaldte humanisering af myten. Til hver af de interesser, hvorimellem Iphigenie splittes, til Thoas og til Orestes, knytter der sig nemlig en mytisk overlevering. Som præstinde i Diana-templet, er hun på den en side forpligtet over for en rituel tradition, ifølge hvilken gudinden fordrer ofringen af enhver fremmed, der når Tauris’ kyst. I genforeningen med Orestes konfronteres hun på den anden side med myten om Tantalus-slægtens forbandelse: fortællingen om, hvorledes de olympiske guder efter stamfaderens formastelse ${ }^{16}$ dømte slægten til generation efter generation at videreføre grusomheden, senest i form af Orestes' hævnakt over for Klytaimnestra, hans flugt fra Eumeniderne og den deraf affødte plan om, som Apollon angiveligt har budt ham, at bortføre gudindebilledet fra Tauris. Iphigenies forløsende beslutning forudsætter en relativering af begge disse mytiske overleveringers autoritet.

Allerede tidligt i dramaet anfægter Iphigenie offertraditionens nødvendighed: „Der missversteht die Himmlichen, der sie / Blutgierig wähnt; er dichtet ihnen nur / die eignen grausamen Begierden an. ${ }^{17}$ At myten humaniseres vil sige, at den på denne måde afsløres som en menneskelig projektion motiveret af psykologiske omstændigheder, men uden teologisk objektivitet. Også over for myten om Tantalus-slægtens forbandelse gør en sådan humanisering sig gældende, idet dens karakter af digtning fremhæves: "... und Dichter singen: Übermut / Und Untreu' stürtzten ihn von Jovis Tisch / Zur Schmach des alten Tartarus hinab. / Ach und sein ganz Geschlecht trug ihren Hass. ${ }^{18}$ På konfliktens højdepunkt, hvor Iphigenie

15. München 1979.

16. I menneskeligt hovmod ville Tantalus, der var inviteret til at spise ved det olympiske bord, prøve gudernes alvidenhed og serverede derfor sin egen søn Pelops for dem. Guderne - på nær Demeter, der spiste et stykke skulder - opdagede spøgen og forbandede Tantalusslægten.

17. J.W. Goethe: Iphigenie auf Tauris v. 532 ff., Sämtliche Werke, Bd. 5, Frankfurt a.M. 1988 ["Den misforstaaer de Himmelske, som troer / dem blodbegjærlige; han lægger kun / sin egen Vildhed ind i deres Væsen. «Således lyder P. Hansens gamle, men ligefremme oversættelse, Iphigenia paa Tauris, København 1893, p. 27]. 
inden den endelige frigørelse for et øjeblik synker tilbage i afmagten, er det således i form af "Das Lied der Parzen", "Skæbnegudindernes sang", som hendes amme har sunget for hende, at myten en sidste gang hævder sig. Myten, antydes det, er en fabel, der kun i kraft af indoktrinering har vundet sit præg af selvfølgelighed.

Anfægtelsen af den mytiske overleverings objektivitet, dens afsløring som subjektiv projektion, er i Goethes drama forudsætningen for, at volden kan overvindes. Konflikten kan nemlig kun løses ved en omfunktionalisering af myten i henhold til den etiske standard, som Iphigenie sætter med sin ærlighed. Idet hun tager den etiske beslutning, erklærer hun over for guderne: „Allein euch leg ich's auf die Kniee! Wenn / Ihr wahrhaft seid, wie ihr gepriesen werdet: / So zeigt's durch euern Beistand und verherrlicht / Durch mich die Wahrheit. « ${ }^{19}$ Den guddommelige magt, som myterne fortæller om, må med andre ord gøre sig fortjent til sin status. »Wenn ihr wahrhaft seid, wie ihr gepriesen werdet ...«: hvor megen kritisk distance vidner denne konditionssætning ikke om!« skriver Rasch. »Iphigenie bedømmer gudernes og de jordiske herskeres handlinger med samme kritiske bevidsthed, og også målestokken er den samme: respekten over for den menneskelige autonomi. $\|^{20}$ Mytens billedlighed må med andre ord legitimere sig over for et etisk princip: „Rettet mich«, siger Iphigenie til guderne, "und rettet euer Bild in meiner Seele! ${ }^{21}$ Hvis myten ikke lever op til dette etiske princip, må og - postulerer værket - kan den ændres.

Den definitive omfunktionalisering af myten sker med omfortolkningen af det orakelord, som har bragt Orestes til Tauris: Ikke Apollons søster, dvs. gudebilledet fra Diana-templet, men sin egen skal Orestes hente. I kraft af denne omskrivning opløses modsætningerne: Orestes behøver ikke at sone drabet af moderen med endnu en forbrydelse, Thoas behøver ikke med vold at hindre et tempelrøveri. I nyfortolkningen konkretiseres samtidig humaniseringen, idet det væsentlige viser sig at være det menneskelige og ikke det guddommelige søskendepar. Opløsningen af forbandelsen involverer ingen guder - at røve idolet fra Diana-templet ville blot have været endnu en forbrydelse i den uendelige række - men derimod en menneskelig indsats dels

18. Op.cit., v. 323 ff. [»og Skjalde synge: Overmod / og Troløshed fra Jovis Bord ham styrted / til Underverdnens Skam og Skændsel ned. / Ak, Guders Had hans hele Slægt forfølger! « P. Hansen, p. 17].

19. Op.cit., v. 1916 ff [»Men nu i Eders Skjød min Sag jeg lægger! / Er Sandhed Eder kjær, som I har Ord for, / saa viis det ved at hjælpe mig og skjænke / Sandheden Sejr ved mig!« P. Hansen, p. 104].

20. Wolfdietrich Rasch: Goethes 'Iphigenie auf Tauris' als Drama der Autonomie, München 1979, p. 94 og 164.

21. Iphigenie, v. 1716 f. [»O, frels mig / og frels Jert eget Billed i min Sjæl!« P. Hansen, p. 92 93]. 
fra Iphigenies side, i form af hævdelsen af det etiske princip, dels fra Thoas side, i form af frigivelsen, dels fra Orestes' side, i form af det terapeutiske sørgearbejde han gennemgår.

Ligesom i Bakkanterne gennemføres altså i Iphigenie auf Tauris en regulering af den mytiske praksis. Hvor dette imidlertid hos Euripides skete ved den dogmatiske installation af et teologisk niveau, der er hævet over den billedlige gudsdyrkelse - altså så at sige i kraft af en teologisering af myten sker det hos Goethe i kraft en humanisering. Jeg har ovenfor forsøgt at indkredse myten som en bearbejdelse af omstændighedserfaringen, der i den rituelle mimesis kan føre til aktualiseringen af den guddommelige magt og den bejaende sammensmeltning med denne. Heroverfor er den dogmatiske regulering af myten udtryk for en bestræbelse på at sætte visse rammer for den ekstatiske aktualisering, at sørge for at de kultiske begivenheder f.eks finder sted i templet og ikke for langt ude i skoven. Den anfægter for så vidt ikke afmagten over for omstændigheden og det objektive behov for i myte og ritual at forholde sig til og i sidste instans bejae denne afmagt. En sådan anfægtelse er derimod humaniseringens indebyrd. Når Iphigenie mener at kunne ændre myten, forudsætter det således troen på, at hun også kan ændre omstændigheden.

De overleveringer, Iphigenie og Iphigenie tager kampen op med, den tauriske offertradition og tantalidernes forbandelse, fremstilles som billedlige projektioner motiveret af psykiske omstændigheder, der netop ikke er uomgængelige. »Die eignen grausamen Begierden« (v. 523), som ifølge Iphigenie er baggrunden for offerritualet, viser sig at kunne overvindes i kraft af den etiske appel til Thoas, og den traumatiserede tilstand, som får Orestes til at tynges af forbandelsen, viser sig at kunne behandles med terapeutiske metoder. Goethe gør meget ud af at fremstille Orestes' katharsiske proces, fra ønsket om at dø, over konfrontationen med Iphigenie og den terapeutiske genfortælling af de traumatiske begivenheder, til den forløsende Hadesvision. ${ }^{22}$ De psykologiske omstændigheders overvindelighed er mulighedsbetingelsen for omfunktionaliseringen af myten, men overvindelsen synes omvendt også at behøve mytens medvirken. Iphigenies appel til Thoas og Orestes' sørgearbejde alene løser ikke konflikten. Først med omfortolkningen af Apollons ord - som på én gang udgør kernen i og litteraturhistorisk afspejler Goethes omfortolkning af Euripides Ifigenie på Tauris ${ }^{23}-$ løses

22. Den fortvivlede Orestes fremmaner, i det ønske snart at slutte sig til dem, alle sine forbandede forfædre forsamlet i dødsriget, og konstaterer til sin forundring, at der her ikke længere gør sig noget fjendskab gældende imellem slægtningene. Hævnspiralen er opløst. Kun Tantalus selv må lide i Hades, hvilket udtrykker transformationen af forbandelsens objektive skyld (arvesynden) til ideen om en subjektiv skyld, som der kun individuelt må stås til regnskab for. Blikket i dybet afføder således en indsigt, der bryder forbandelsen og gør Orestes klar til at genopstå fra dødsriget. 
konflikten. Myten må udformes, så den samarbejder med bestræbelsen på at overvinde den voldelige omstændighed.

Hvor den dogmatiske regulering i Bakkanterne fastholder den religiøse bejaelse, bunder Iphigenies humanisering i hensynet til sædelighed forud for religiøsitet: myten bliver til et kodeks for sædeligheden, i dette tilfælde et hensigtsmæssigt budskab om menneskelig søskendekærlighed. Myten skal ikke længere fungere som en besværgende, men som en opbyggelig fortælling. Dette forudsætter en relativering af mytens objektivitetsstatus. Virkningen af den dogmatiske regulering afhænger, som det viste sig i Bakkanterne, af dens insisteren på, at mytens billedlighed har en objektiv teologisk referent, som den må stå til regnskab overfor. Humaniseringen derimod tager udgangspunkt i afskrivningen af den teologiske referent. På den baggrund kan den mytiske fortælling i stedet forpligtes over for et dybere liggende etisk princip. Som det fremgår af dialogen med Thoas, leder Iphigenies afsløring af overleveringen som ren subjektivitet til erkendelsen af denne egentligt forpligtende referent: »Thoas: Ein alt Gesetz, nicht ich, gebietet dir. / Iphigenie: Wir fassen ein Gesetz begierig an, / Das unsrer Leidenschaft zur Waffe dient. / Ein andres spricht zu mir, ein älteres, / Mich dir zu widersetzen, das Gebot, / Dem jeder Fremde heilig ist. ${ }^{24}$

\section{Humanisering af myten $i$ Penthesilea}

Inden for rammerne af Goethes Iphigenie giver det altså god mening at tale om en humanisering af myten. Når jeg nu tager fat på behandlingen af Penthesilea (udg. 1808), Kleists sørgespil om amazonedronningens blodige forelskelse i den græske helt Akilleus, er det med udgangspunkt i spørgsmålet, hvorvidt man i forbindelse med dette drama vil kunne tale om en lignende humanisering. På dette spørgsmål har f.eks. Jochen Schmidt i Heinrich von Kleist - Studien zu seiner poetischen Verfahrensweise svaret bekræftende. I udfoldelsen af sin tese tager Schmidt udgangspunkt i Penthesileas forhold til den mytiske overlevering, der knytter sig til amazonesamfundet, og som placerer hende som frontfigur i gennemførelsen af amazone-kulten. Karakteren af denne religiøse praksis - og således baggrunden for at amazonerne, til de græske hærlederes (Odysseus, Diomedes og Antilo-

23. Hos Euripides løses konflikten ikke ved menneskelige midler, men derimod ved en klassisk deus ex machina, idet Athene til slut åbenbarer sig og dikterer Iphigenies løsladelse.

24. Iphigenie, v. 1831 ff. [«Thoas: En gammel Lov dig byder, ikke jeg./ Iphigenie: En Lov vi tager ivrigt Tilflugt til,/ naar den vor Lidenskab til Vaaben tjener./ En anden Lov, en ældre, byder mig/ at staa imod din Villie: det er den,/ som holder hver en fremmeds Liv for helligt«, P. Hansen, p. 100]. 
chus) forundring, kaster sig ind midt i den trojanske krig - forbliver uforklaret indtil den centrale samtale imellem Penthesilea og Achilles i dramaets 15. scene: Hver gang amazonedronningen vil bringe samfundet fornyelse, fortælles det her, »ruft sie die blühndsten / der Fraun, von allen Enden ihres Reichs, / Nach Themiscyra hin, und fleht, im Tempel / Der Artemis, auf ihre jungen Schösse / den Segen keuscher Marsbefruchtung nieder. ${ }^{25}$ Som et rent kvindesamfund er amazonerne, for at opretholde befolkningen, nødt til at indhente mandlig sæd udefra, hvilket altså sker inden for rammerne af en rituel dyrkelse af Artemis (Diana) og Ares (Mars). »Dianas heil'ge Priesterin«fortsætter Penthesilea«, verfügt / Auf dies Gesuch sich in den Tempel Mars', / Und trägt, am Altar hingestreckt, dem Gott / Den Wunsch der weisen Völkermutter vor. / Der Gott dann, wenn er sie erhören will, [...] / Der Gott zeigt uns, durch seine Priesterin, / Ein Volk an, keusch und herrlich, das, statt seiner, / Als Stellvertreter, uns erscheinen soll. ${ }^{26}$ Den tilsyneladende formålsløse krigeriske adfærd, der fuldstændig bryder den trojanske krigs logik, er altså at forstå som en mytisk motiveret kulthandling. Amazonerne drager i krig for at erobre Mars' stedfortrædere, som de ved den såkaldte rosenfest iscenesætter rituelt og, muligvis i forbindelse med deres ofring, lader sig befrugte af.

Dramaets egentlige konflikt ligger imidlertid ikke, som det ved første øjekast kunne synes, i forholdet imellem amazonernes feminint gådefulde brutalitet og grækernes maskulint måbende rationalitet, men derimod i Penthesileas forhold til amazone-traditionen. Penthesileas krigsfærd, kampen mod Achilles, viser sig at drives af noget ganske andet end denne overlevering. Ifølge den kultiske praksis har Mars udpeget de hellenske krigere som kollektiv til sine stedfortrædere. Det, som Penthesilea derimod så lidenskabeligt søger på slagmarken, er at besejre og hjemføre Achilles som individ. Den lidenskab, der karakteriserer mellemværendet med Achilles, transcenderer amazonetraditionens funktionalitet, og er ud fra kultens synspunkt en formastelighed, der hænger sammen med en krise i amazonetraditionens overlevering fra generation til generation. Som Penthesilea fortæller i 15. scene, var det interessant nok netop hendes moder, hvis lederrolle hun skulle arve, der på sit dødsleje brød med traditionen, idet hun udpegede Achilles som datterens bytte: »Penthesilea: Sie nannt ihn, [...] wie's einer

25. Heinrich von Kleist: Penthesilea, v. 2034 ff., in Sämtliche Werke und Briefe, Bd. 2, Frankfurt a. M. 1987 [”... så indkalder hun fra alle ender af riget de mest blomstrende af jomfruerne til Themiscyra, og i Artemis' tempel nedkalder hun til deres unge skød den kyske Mars-befrugtelses velsignelse.« Min oversættelse.].

26. Op.cit., v. 2044 ff. ["Dianas hellige præstinde begiver sig i dette ærinde til Mars’ tempel og fremfører, henstrakt mod gudens alter, den vise folkemoders ønske. Hvorefter guden, hvis han vil høre hende, $[. .$.$] gennem sin præstinde anviser os et folk, kysk og herligt, der i hans$ sted, som hans stedfortræder, skal vise sig for os«]. 
Mutter / wohl im Vertraun zu ihrer Tochter ziemt. / Achilles: Warum? Weshalb? Verbeut dies das Gesetz? / Penthesilea: Es Schickt sich nicht, dass eine Tochter Mars' / Sich ihren Gegner sucht, den soll sie wählen, / Den ihr der Gott im Kampf erscheinen lässt. ${ }^{27}$ Med sin besættelse af Achilles som individ nedkalder Penthesilea derfor overpræstindens fordømmelse over sig: "Was«, siger kultinstitutionens repræsentant "geht dem Volk der Pelide an? / - Ziemt's einer Tochter Ares', Königin / Im Kampf auf einen Namen sich zu stellen. ${ }^{28}$

Når Jochen Schmidt i tråd med den Iphigenie-læsning, som jeg ovenfor har præsenteret, udlægger Penthesilea som et humaniserende opgør med mytens magt, er det med udgangspunkt i dette konfliktforhold imellem amazonetraditionen og Penthesileas enegang, der hos Schmidt udlægges som »det fri kærlighedsvalg«, og således jævnføres med den autonomi, hvormed Iphigenie konfronterer mytens voldelighed. At den mytiske overlevering i Penthesilea er voldelig, ikke blot over for omgivelserne, men også over for amazonerne selv, ser Schmidt frem for alt i amazonernes kendetegn, det afrevne bryst. Netop med denne voldelighed, denne pervertering af den naturlige menneskelighed: den første dronning, Tanaïs afrivning af brystet med henblik på fremtidig bueskydning, indstiftes traditionen. Denne tradition er det, som Penthesilea, ifølge Schmidt som en anden Iphigenie, løsriver sig fra og i sidste ende opløser med ordene "Der Tanaï Asche, streut sie in die Luft! ${ }^{29}$

Og nøjagtig som i Iphigenie går vejen til frigørelse fra myten via humaniseringen, dvs. via afsløringen af de mytiske forestillinger som projektioner betinget af menneskelige problemer. Schmidt slår således ned på de vers, hvor Penthesilea forklarer amazonelovens oprindelse: „Achilles: Und woher quillt, von wannen ein Gesetz,/ Unweiblich, du vergibst mir, unnatürlich,/ Dem übrigen Geschlecht der Menschen fremd?/ Penthesilea: Fern aus der Urne alles Heiligen,/ O Jüngling: von der Zeiten Gipfeln nieder,/ Den unbetretnen, die der Himmel ewig/ In Wolkenduft geheimnisvoll verhüllt./ Der ersten Mütter Wort entschied es also, / Und dem verstummen wir, Neridensohn,/ Wie deiner ersten Väter worten du. ${ }^{30}$ I disse linjer ser Schmidt netop en afsløring af det foregivne absolutte i myten. Først henviser Penthesilea til en guddommelig uroprindelse, men siden afslører hun, med henvisningen til den første dronning, at mytens oprindelse ikke er mindre historisk og men-

27. Op.cit., v. 2142ff. [»Penth: Hun benævnte ham, [...] som det måske nok sømmer sig i fortrolighed mellem moder og datter. Ach: Hvorfor? Forbyder loven da det? Penth: Det passer sig ikke for en af Mars' døtre selv at udsøge sig sin modstander. Hun skal vælge den, som guden under kampen lader vise sig for hende«].

28. Op.cit. v. 1044 ff. ["Hvad kommer peliden folket ved? Sømmer det sig, dronning, for en af Ares' døtre i kampen at bestemme sig for ét navn? «].

29. Op.cit., v. 3009 [»Tanaïs aske, spred den for vinden!«]. 
neskeligt betinget end alt andet. Indstiftelsen af myten og kulten beror på en historisk begivenhed, amazonesamfundets tilgrundliggende traume, ${ }^{31}$ hvilket myten med sin sakrale aura blot formår at kamouflere: "Således« skriver Schmidt, "indeholder denne underretning ikke blot henvisningen til forhistorien, men også den vigtige blotlæggelse af amazonernes forkastelige afhistorisering af det historisk tilblevne. Blot i kraft af alderen tillægges det forgangne fejlagtigt en sakral status. »Urne alles heiligen«, »Himmel«, »ewig« - dette er de velkendte pseudoreligiøse projektioner, hvormed Kleist karakteriserer Penthesileas bevidsthed som fanget i en kollektiv vrangforestilling. Fra denne indhyllende og tilfangetagende sfære, hvis petrefakt overpræstinden udgør, må heltinden frigøre sig igennem en smertefuld erkendelsesproces. $\ll^{32}$

Også hos Kleist kan man altså finde ansatser til en kritisk afskrivning af mytens teologiske referent og dermed en afsløring af myten som menneskeligt motiveret projektion. Nu er det imidlertid ikke nogen hemmelighed, at Kleists drama ender med mere blod og færre konstruktive løsninger end Goethes Iphigenie. Efter at Penthesilea og Achilles to gange er tørnet sammen på slagmarken, og efter at han i scenerne 14-15, for at de to skal kunne forenes, har foregivet at være Penthesileas fange, blusser kampen igen op og de elskende rives fra hinanden. Herefter udfordrer Achilles til en tredje kamp, i den hensigt igen at lade sig tage til fange. På dette tidspunkt har Penthesileas lidenskab, bestående af lige dele brutalitet og forelskelse, imidlertid nået en sådan grad af utøjlelighed, at hun med sit hundekobbel overmander Achilles og i ekstase sætter tænderne i ham. Som en amazone beretter: "Sie schlägt, die Rüstung ihm vom Leibe reissend, / Den Zahn schlägt sie in seine weisse Brust «. ${ }^{33}$

30. Op.cit., 1902 ff. ["Ach: Og hvori oprinder en sådan lov, ukvindelig - tilgiv mig - , unaturlig, fremmed for den øvrige menneskeslægt? Penth: Fjernt, fra alle helligdommes urne, o yndling, nedgivet fra tidens tinder, de ubetrådte, som himmelen for evigt hyller i hemmelighedsfulde tåger. Ved den første moders ord afgjordes det altså, og heroverfor forstummer vi, neridesøn, som du over for din stamfaders ord «].

31. Den traumatiske begivenhed, der refereres til, er Etiopier-kongen Vexoris' angreb på det skyttiske samfund, kvinderne oprindeligt indgik i, udslettelsen af den mandlige befolkning og de systematiske overgreb på kvinderne. Det er som reaktion på denne begivenhed, at kvinderne, efter at de ved list har gjort det af med de etiopiske voldsmænd, beslutter sig for aldrig mere at skulle være afhængige af mænd.

32. Jochen Schmidt: Heinrich von Kleist - Studien zu seiner poetischen Verfahrensweise, Tübingen 1974, p. 41.

33. Penthesilea, v. 2669 f. ["Idet hun flår rustningen af hans krop, støder hun tanden i hans hvide bryst«]. 


\section{Dionysisk distanceløshed}

Den tragiske udvikling, som dramaet gennemspiller, indebærer inden for rammerne af Jochen Schmidts læsning ikke nogen fundamental problematisering af Penthesileas humaniseringsbestræbelse. At frigørelsen fra myten går via død og ødelæggelse vidner ifølge Schmidt blot om graden af mytens indgroethed. Som det hed ovenfor er det netop »en smertefuld erkendelsesproces«, Penthesilea må gennemgå for at overvinde myten. De kannibalistiske scener i dramaets slutning forstyrrer således ikke oplysningens triumf blot må Penthesileas humanisering af myten/traumet i modsætning til Iphigenies gå omvejen omkring tragikken: »Idet hun gennemlever [amazonesamfundets voldelighed] til den bitre ende, kan hun overvinde den; i den tragiske erkendelse, som kulminerer i formuleringen: „Der Tanaï Asche, streut sie in die Luft.«Idet hun går i døden, er hun ikke længere amazone«. ${ }^{34}$ Over for en sådan insisteren på læsningen af Penthesilea som et humaniseringsdrama må der imidlertid spørges, om tragikken ikke netop indebærer et afgørende brud med humaniseringen, om den blot er udtryk for en gradsforskel i opgavens vanskelighed, med andre ord om Penthesilea virkelig bør læses som en anden, blot mere smertefuld Iphigenie.

Umiddelbart inden Iphigenie tager det store etiske skridt og afslører sin og broderens flugtplan, spørger hun: »Muss ein zartes Weib / Sich ihres angebornen Rechts entäussern, / Wild gegen Wilde sein, wie Amazonen / Das Recht des Schwertes euch rauben und mit Blute / Die Unterdrückung rächen?« »Auf und ab«, fortsætter hun »Steigt in der Brust ein kühnes Unternehmen. $\aleph^{35}$ Dette dristige foretagende udgør svaret på hendes spørgsmål: Nej, en kvinde i hendes situation behøver ikke at reagere med amazonernes mytiske vold, når hun i stedet med sin ærligheds appel kan gennemføre en etisk omfunktionalisering af myten. Måske er netop disse vers, hvor Goethe synes at opstille et alternativ imellem humanitetens og barbariets vej, udgangspunktet for Kleists drama og valget af amazone-stoffet således udtryk for et ønske om at undersøge den vej, man må gå, hvis man netop ikke, eller kun halvvejs, kan gå Iphigenies.

Som det fremgik af Iphigenie-læsningen forudsætter overvindelsen af mytens magt en overvindelse af selve den omstændighed, som myten er udtryk for. Det er ikke nok at myterne afsløres som menneskelige projektioner uden forankring i en teologisk instans. Både Thoas’ forstokkethed og

34. Schmidt op.cit., p. 39 .

35. Iphigenie, v. 1908 ff. ["Kan Kvinden intet øve? Skal hun kaste / den Svaghed fra sig, som er hendes Væsen / og være vild mod Vilde, røve Jer, / lig Amazoner, Sværdets Ret og hævne / med Blod sin Underkuelse? En dristig, / en stor Beslutning bølger i mit Bryst«, P. Hansen, p. 104]. 
Orestes' traume, de to menneskelige problemer, som omstændigheden viser sig at kunne reduceres til, må løses, som det sker i kraft af henholdsvis Iphigenies etiske appel og Orestes' traumebehandling. Begge disse problemer præsenteres i god oplysningsånd for fornuftige løsninger, der i selve dramaets forløb kan realiseres. Penthesileas mytekritik derimod når aldrig sin fuldbyrdelse i en succesfuld behandling af amazone-traumet. Med Penthesileas spredning af Tamaïs aske følger ingen konstruktive løsninger, ingen opstilling af et etisk princip, hvormed mytens vold kan modvirkes og derfor heller ingen human omfunktionalisering af myten. Snarere synes opløsningen af amazonernes institutionaliserede myte at udløse en ekstatisk brutalitet, der repræsenteres ved det dionysiske vanvid, som også thebanerne i Bakkanterne besattes af. Dette sker med direkte reference til Euripides. Når Penthesilea ender med at sønderflå og fortære den elskede er det således i egenskab af mænade, mere præcist som en spejling af Agaue der med samme fråde om munden (jf. Bakkanterne, v. 1099) sønderflår sønnen Pentheus: "Jetzt unter ihren Hunden«, hedder det om Penthesilea, "wütet sie, / mit schaumbedeckter Lipp, und nennt sie Schwestern, / Die heulenden, und der Mänade gleich, / Mit ihrem Bogen durch die Felder tanzend, / Hetzt sie die Meute, die mordatmende, / Die sie umringt, das schönste Wild zu fangen, / Das je die Erde, wie sie sagt, durchschweift. ${ }^{36}$

Hen imod slutningen afslører Kleists værk sig altså som en litterær bearbejdelse af elementer af Bakkanterne. Dette viser sig i en række detaljer: f.eks lader Kleist Achilles stryge Penthesileas kind, nøjagtig som Pentheus stryger Agaues (Bak. 1094, Penth. 2663), og han lader ham gemme sig i et grantræ ligesom Pentheus (Bak. 1048, Penth. 2637), men frem for alt er det i selve den dionysiske ekstase, som Penthesilea gribes af, at Kleist genoptager og kommenterer Euripides. Sammenligner man nu betydningen af den religiøse ekstase i de to dramaer, må man hos Euripides især hæfte sig ved dens straffunktion, dvs. dens motivering som det middel, hvormed Dionysos søger at tiltvinge sig den ønskede respekt fra Thebens borgere. Som jeg har foreslået $\mathrm{i}$ afsnit 2, hænger denne forklaring af det dionysiske vanvid sammen med mytens dogmatiske selvregulering, dvs. bestræbelsen på at stille kultvirksomheden til regnskab over for dens guddommelige referent. Afgørende for denne pointe er, at der i Bakkanterne opretholdes en distance imellem bakkantindernes dionysiske ekstase og den teologiske instans Dionysos. Netop en sådan distance finder man ikke i Penthesilea. Som Bernhard Böschenstein konstaterer: »I Bakkanterne fandt Kleist den diony-

36. Penthesilea, v. 2567 ff. [»Med skumbedækket læbe raser hun nu blandt hundene, de hylende, som hun kalder sine søstre, og som mænaderne dansende med deres buer hen over markerne, driver hun det mordprustende kobbel frem, som omgiver hende, for, som hun siger, at fange det skønneste stykke vildt, der nogensinde har strejfet på jorden«]. 
siske ekstase realiseret. Men selv opererer han aldrig eksplicit med Dionysos som en veldefineret guddom, der lader sig skelne fra mennesket. $\aleph^{37}$ Der er med andre ord ingen teologisk instans, i henhold til hvilken der vil kunne formuleres et korrektiv til den guddommelige besættelse, Penthesileas lidenskab udvikler sig til. »Den distanceløshed« fortsætter Böschenstein, »som kendetegner Penthesileas adfærd, skyldes umuligheden af at relativere og afgrænse dramaet ud fra gudens fixpunkt»(»BE«, p. 250). Meget taler for, at denne forskelsløshed er baggrunden for den utøjlelighed der præger såvel figuren som værket Penthesilea. Om hun føler sig "som dyr eller gudinde bliver et og det samme« (»BE«, p. 252).

Fraværet af distance til referenten tematiseres insisterende i Penthesileas slutning; som distanceløshed imellem ritualets mimetiske gudsbilledlighed (Penthesileas mænadiske adfærd) og den teologiske instans (Dionysos) og som distanceløshed imellem sprog og virkelighed. Da Penthesilea efter Sparagmos-scenen, ligesom Agave, oplyses om hvad hun har gjort, kommer hun med følgende forklaring: »So war es ein Versehen. Küsse, Bisse,/ Das reimt sich, und wer recht von Herzen liebt,/ Kann schon das eine für das andere greifen. $\|^{38} \mathrm{Og}$ lidt senere hedder det: "Wie manche, die am Hals des Freundes hängt, / Sagt wohl das Wort: sie lieb' ihn, o so sehr/ Dass sie vor Liebe gleich ihn essen könnte,/ Und hinterher das Wort geprüft, die Närrin!/ Gesättigt sein' zum Ekel ist sie schon./ Nun, du geliebter, so verfuhr ich nicht./ Sieh hier: als ich an deinem Halse hing, Hab,/ Hab ich's wahrhaftig Wort für Wort getan;/ Ich war nicht so verrückt, als es wohl schien. ${ }^{39}$ I sine udlægninger kredser Penthesilea på denne vis om den tanke, at billedsproget hos hende ikke blot forholder sig refererende til den blodige virkelighed, men selv skaber den. Denne det digteriske sprogs påkaldende magt kulminerer i hendes afsluttende selvmord, udført med en metaforisk dolk: »Denn jetzt steig ich in meinen Busen nieder,/ Gleich einem Schacht, und grabe, kalt wie Erz,/ Mir ein vernichtendes Gefühl hervor./ Dies Erz, dies läutr' ich in der Glut des Jammers/ Hart mir zu Stahl; tränk es mit Gift sodann,/ Heissätzendem, der Reue, durch und durch; /trag es der Hoffnung ew'gem Amboss zu,/ Und schärf und spitz es mir zu einem Dolch;/ Und diesem

37. Bernhard Böschenstein: „Die Bakchen des Euripides in der Umgestaltung Hölderlins und Kleists«, in Stanley A. Corngold et. al (red): Aspekte der Goethezeit, Göttingen 1977, p. 250 (herefter »BE«).

38. Penthesilea, v. 2981 ff [»Så var det en forveksling. At kysse, at bide, det rimer på hinanden, og den, der elsker af hele sit hjerte, kan godt tage det ene for det andet«].

39. Op.cit., v. 2991 ff [»Ligesom mange, der hænger ved den elskedes hals, bruger talemåden: at hun elsker ham, åh, så højt, at hun ligesom af kærlighed kunne spise ham, og bagefter, når ordene er blevet efterprøvet, er hun allerede, den nar!, kvalmende mæt af ham. Nuvel, min elskede, sådan bar jeg mig ikke ad. Se her: idet jeg hang om din hals, gjorde jeg det virkelig ord for ord. Jeg var ikke så forrykt, som det nok har syntes»]. 
Dolch jetzt reich ich meine Brust: / So! So! So! Und wieder! - Nun ist es gut. I ( sie fällt und stirbt.). ${ }^{40}$

Den skaberkraft, som billedsproget her besidder, er oplagt at forbinde med den mytiske billedligheds aktualiseringspotentiale. Penthesileas ord bliver til virkelighed på samme måde som den kristne mytes ord: „dette er mit legeme, ... dette er mit blod «, - for at tage et kendt eksempel - bliver til virkelighed i nadverritualet. Penthesileas kannibalistiske brutalitet fremtræder med andre ord som den dæmoniske aktualisering i dens mest utøjlede udgave. Dette må blive bestemmende for svaret på Jochen Schmidts humaniseringstese. Hvor humaniseringen ved en afmontering af den teologiske referent søger at bane vejen for en etisk afvæbning af myten, viser Kleist med sin genoptagelse af Bakkanterne, hvorledes netop fraværet af referenten frigør distanceløshedens barbari; hvor Schmidt i Penthesilea hepper på Iphigenies frigørelse fra teologiens magt, problematiserer Kleists værk selv altså tabet af mytens teologiske selvregulering og konsekvenserne heraf. På den baggrund synes ånden i Penthesilea i sidste instans snarere at være oplysningskritisk end mytekritisk. ${ }^{41}$ Eller rettere: værkets tematisering af myten sprænger den oplysning-antioplysningslogik, inden for hvilken Schmidt ønsker at mobilisere Kleist imod myten. Værket iscenesætter en situation, hvor humaniseringen ikke lader sig gennemføre, og hvor resultatet af den oplyste mytekritik derfor snarere synes at være et tilbage- end et fremskridt, da den fratager myten netop det dogmatiske element, der forhindrer gudsbilledlighedens aktualisering $\mathrm{i}$ at blive nøjagtig lige så voldelig som den omstændighed, myten tjener til at give form. ${ }^{42}$

Situationen ligner den, som René Girard i hårrejsende vendinger beskriver under navnet »transcendensens forfald«. Som skitseret i afsnit 2 må den

40. Op.cit., v. 3025 ff. ["Som i en skakt stiger jeg ned i mit bryst og fremgraver, kold som malm, følelsen af tilintetgørelse. I jammerens flammer lutrer og hærder jeg denne malm til stål; fugter den med hedt ætsende gifte, angeren, igen og igen; bærer den til håbets evige ambolt og skærper og spidser mig derudaf en dolk. Og denne dolk skænker jeg mit bryst: Sådan! Sådan! Sådan! Sådan! Og igen! Så er det godt. (Hun falder om og dør.)《].

41. Som repræsentant for den mytekritiske læsning kan man ved siden af Jochen Schmidt nævne Doris Claudia Borelbachs Mythos-Rezeption in Kleists Dramen, Würzburg 1998.

42. Man kan måske tale om en regression til en slags totemdyrkelse: den religiøsitet, der kommer ud af det, når de ekstatiske mænader i dyrkelsen af gudsbilledligheden, deres thyrsos, hjorteskind, vedbend og slanger, besættes af disse genstandes umiddelbare nærvær, glemmer disses henvisende funktion, og dermed også at de ikke selv er vilddyr, men mennesker, der rituelt dyrker en dyrelignende gud. At der i Penthesilea skulle være tale om et sådant tilbagefald fra en mytisk til en totemistisk religiøsitet, er Gerhard Neumann inde på, idet han omtaler logikken i Kleists drama som »vor-antikisch, vor-human« ("Erkennenungsszene und Opferritual in Goethes Iphigenie und Kleists Penthesilea«, in Günther Emig et. al (red): Käthchen und seine Schwestern, Heilbronn 2000, p. 78). Med henblik på Penthesileas kannibalistiske bliven ét med Achilles, er det værd at bemærke, at indtagelse traditionelt er en måde at tage del i totem-genstanden på. Et totemistisk element, der for så vidt stadig er at finde i det kristne nadverritual. 
katartiske proces, som Girard beskriver, bevæge sig igennem to faser: først ritualets radikalisering af den immanente vold, den totale forskelsløshed, siden den ny forskelssættelse i udpegelsen og udstødelsen af syndebukken. Myten tjener til at legitimere denne forskelssættelse ved at tilskrive en guddommelig instans udstødelsens voldelighed. Det er med andre ord nødvendigt for opretholdelsen af samfundets stabilitet at transformere den immanente vold til en transcendent vold, eller, som Girard skriver, "at tænke denne vold som overmenneskelig, for at kunne holde den på distance og blive af med den. Hvis den af rædsel stivnede tilbedelse svækkes, « fortsætter han, "hvis forskellene begynder at opløse sig, så mister de rituelle ofringer deres effekt: de bliver ikke længere accepteret. Alle foregiver selv at kunne rede situationen, men ingen er i stand til det: netop transcendensens forfald fører til, at der ikke længere består den mindste forskel imellem ønsket om byens redning og den uhæmmede ambition, imellem den oprigtige tro og ønsket om at guddommeliggøre sig selv«(VS, p. 192).

Mytekritikens afsløring af mytens arbitraritet indebærer således ifølge Girards teori ikke en overvindelse af den vold, som i myten er blevet transcendent, men derimod en frisættelse af den immanente vold, den rituelle mimesis' løben løbsk. „Den antireligiøse afmystificering«, hedder det, »tjener på ingen måde fredens og den almene fornufts sag, sådan som man forestiller sig det i en verden, der er blind for den rolle, volden spiller i det menneskelige samfund. Snarere viser den sig som ligeså dobbelttydig som religionen selv, idet den bekæmper en type vold blot for at give næring til en anden og utvivlsomt frygteligere« $(V S$, p. 194). Om disse oplysningskritiske formuleringer kan man mene hvad man vil, men i forbindelse med læsningen af Penthesilea har de et væsentligt forklaringspotentiale. Penthesileas dionysiske distanceløshed, den 100\% inkarnerede referent, er netop det løbskløbne rituals forskelsløshed: dyr, menneske og gud i et.

\section{Utopisk og dæmonisk remytologisering}

Ligesom Girard taler Ulrich J. Beil i en kommentar til Penthesilea om transcendenstab. Dog her ikke med de myteteoretiske termers abstrakthed, men derimod konkret historisk, idet han fokuserer på 1700-tallets sækulariseringsproces. Beil forstår i denne forbindelse ikke, som det er almindeligt, sækulariseringens konsekvenser som en afskaffelse af Gud, men som en afskaffelse af hans transcendens.

»Det Andet, som i den kristne eksistensfortolkning var forankret i en imaginær himmel, lod sig fra et vist tidspunkt ikke legitimere som prin- 
cipielt fraværende. Den immanente eskatologi, som tiltrak mange intellektuelle efter 1789, førte og forførte til en løsrivelse af det Andet fra den traditionelle signifiés skyrige. Den blot imaginære andethed oplevedes som en mangel, der skulle afhjælpes ved æstetisk, filosofisk, etnologisk produktion på signifiantens niveau. Fra nu af syntes det forældet blot at henvise til det Andet; det drejede sig i højere grad om selv at frembringe det i teksterne ved hjælp af fremmedgørelse, irritation af læserforventningen og et nyt symbolbegreb. ${ }^{43}$

Ifølge Beil er nedbrydelsen af det kristne verdensbillede, der dogmatisk placerede det guddommelige som en referent i himlen, med andre ord forudsætningen for udviklingen af den romantiske kunstreligion. Til dennes dyrkelse af kunsten som bærer af en sakral erfaring hører den såkaldte remytologiseringsbevægelse, med dens forsøg på at genopvække Dionysos som 'den kommende gud':

»Dionysos er det litterære paradigme på dette forandrede behov for det Andet, som jeg netop har talt om. Med ham når den klassicistiske mytereception sin afslutning. Myten om 'den kommende gud', der hos Hölderlin og Novalis får utopiske, hos Kleist dæmoniske træk (jf. den respektive Euripides-reception) afslutter repræsentationens æstetik og fører over i en ncervarets astetik [...] Dionysos afløser frelseren, idet han fylder den eskatologiske struktur med et nyt jordisk, sanseligt indhold. Han er Bogens forløser, den skrækkens og ekstasens galionsfigur, med hvilken den moderne kunst fra nu af fejrer sin autonomi. ${ }^{44}$

Beil kobler på den måde transcendenstabet og den dionysiske distanceløshed med de romantiske digteres hyppige proklamering af en ny mytologi og tæller i den forbindelse tilsyneladende Kleist blandt remytologiseringsdigterne. Dette gør det relevant at stille spørgsmålet, om Penthesilea, nu når opfattelsen af værket som slet og ret mytekritisk i det foregående er blevet tilbagevist, omvendt skal opfattes som et remytologiseringsværk. En sådan opfattelse finder man f.eks. i Jörg Ennens Götter im poetischen Gebrauch: "Den mytologiske billedlighed i Penthesilea«, skriver Ennen, »tjener til at udvikle en poetisk formel, der er uafhængig af fornuften, og til at hjælpe fantasien til en ny sproglig autonomi, der er en afgørende betin-

43. Ulrich J. Beil: »Kleists 'Penthesilea' und die Rolle des Anderen in der Mythosrezeption um 1800«, in Eijiro Iwasaki et.al (red): Begegnung mit dem 'Fremden', bd. 9, München 1991, p. 294.

44. Op.cit., p. 295. 
gelse for grundlæggelsen af en ny kunstmyte ${ }^{45}$ Denne ambition om skabelsen af en ny myte, lanceres hos Ennen som et svar på den moderne, dvs. post-antikke, affortryllelsesprocess. Under henvisning til Kleists tekst "Om Marionetteatret«tales der om et »erkendelsens syndefald», hvorved mennesket har mistet en oprindelig mytisk erfaring af gudernes umiddelbare nærhed i det jordiske - guderne der siden enten er blevet bortrationaliseret eller på monoteistisk vis placeret i transcendensen - og således, fremmedgjort fra verden, er henvist til sin egen refleksivitet. På denne baggrund påtager kunsten sig den opgave at genfortrylle verden, ved fantasiens kraft at invitere de eksilerede guder, frem for alt Dionysos, til igen at indtage scenen.

Når der på denne måde tales om en "ny kunstmyte«, lægges der vægt på mytens evne til at fremmane erfaringen af et guddommeligt nærvær. Det er tydeligt, at dette mytebegreb ikke tager højde for det distancerende og dogmatiske element, som jeg har forsøgt at arbejde med. Hvis myten skal forstås slet og ret som aktualisering, som den inkarnation af det guddommelige i en billedlig, evt. sprogbilledlig, form, som store dele af romantikkens litteratur angiveligt sværmede for, så må Penthesilea betragtes som en dårlig repræsentant for remytologiseringen. Snarere kunne man sige, at værket indebærer en gendrivelse af selve den forudsætning, som den romantiske higen efter en ny myte bygger på, nemlig det jeg vil kalde den deskriptive affortryllelse, dvs. selve det postulat, at verden i kraft af den sejrende rationalitets afsløring af gudeforestillingernes arbitraritet gradvist er blevet tømt for sakral energi. Denne deskriptive affortryllelse må skelnes fra det, man kunne kalde den normative affortryllelse: den holdning, der ikke tager udgangspunkt i det guddommeliges fravær, men derimod i behovet for at værne sig imod dets nærvær. Denne holdning kommer til udtryk i det jødiske billedforbud og i den kristne betræbelse på at forvalte nærværserfaringen. Mit udgangspunkt for fremstillingen her har været den idé, at man også i forbindelse med den hedenske mytes dogmatiske selvregulering kan tale om et vist omfang af normativ affortryllelse. Idet myten stiller sin billedlighed til regnskab over for den teologiske referent, sætter den visse rammer omkring billedlighedens potentielle aktualisering af det sakrale.

Penthesilea tager ikke, som remytologiseringen, udgangspunkt i det sakrales fravær for på den baggrund at hige efter dets genkomst, men viser derimod i form af den dionysiske distanceløshed det sakrales nærvær netop i en situation, hvor det i kraft af den transcendente referents fravær er blevet alt for nærværende. Det er muligvis denne forskel, Ulrich J. Beil ønsker at gøre opmærksom på, når han skelner imellem den »utopiske« genopvækkelse af Dionysos-figuren hos Novalis og Hölderlin og så Kleists »dæmoniske».

45. Jörg Ennen: Götter im poetischen Gebrauch, Münster 1998, p. 341. 
Bernhard Böschenstein tematiserer noget lignende, idet han sammenligner Kleists Dionysos-reception med Hölderlins. »Hölderlins Dionysos«, forklarer Böschenstein, »betød det førsprogliges bliven sprog« (dvs. at den ny myte utopisk medfører en formidling imellem det jordiske og det guddommelige i kraft af arbejdet med det digteriske sprog). „Kleists Dionysos», fortsætter han »betød sprogets forvandling til førsproglig - eller eftersproglig - virkelighed« (dvs. den ufrivillige inkarnation, distanceløsheden imellem sprog og virkelighed, som konkretiseredes i Penthesileas dræbende billedsprog). "Retningen er den omvendte« (»BE«, p. 249). Hvor Hölderlin altså ifølge Böschenstein tilstrceber en aktivering af det metaforiske sprogs distanceovervindende potentiale, tager Kleist udgangspunkt i distanceløsheden som en kendsgerning og rejser dermed spørgsmålet om, hvad der kan gøres ved den. Snarere end at hige efter en overvindelse af den deskriptive synes Penthesilea således at erindre om behovet for en normativ affortryllelse.

\section{Afslutning}

I Goethes Iphigenie stilles spørgsmålet: Hvorfor bøje sig for gudernes magt, når de blot er illusioner, og når den menneskelige afmagt, som forlener disse illisioner med deres sakrale aura, lader sig overvinde ved oplyst og etisk opførsel? Et spørgsmål, det er relevant at stille, mens der arbejdes på den deskriptive affortryllelse. Den utopiske remytologisering stiller i opposition hertil det spørgsmål, der bliver relevant, idet den deskriptive affortryllelse synes at være gennemført: Hvordan kunsten ud af sin billedlighed kan skabe en ny mytologi og dermed genfortrylle verden. Penthesilea er ikke et udtryk for en sådan utopisk remytologiseringsbestræbelse. Derimod rejser værket med sin iscenesættelse af den dionysiske distanceløshed et tredje spørgsmål; et spørgsmål, der er brug for at stille i den situation - og det var måske den historiske situation Kleist fandt sig selv i - hvor det viser sig, at den deskriptive affortryllelse ikke har kunnet holde så meget, som den lovede, nemlig at overvinde både myten og omstændigheden: Det dobbelte spørgsmål om, hvad der sker med omstændighedserfaringen, når det ikke længere er en mulighed at distancere sig fra den ved hjælp af myten, og hvad der sker med mytens billedlighed, når den adskilles fra mytens dogmatiske element, og billedets virkninger derfor ikke kan stilles normativt til regnskab over for den teologiske referent. For det er netop faren ved den deskriptive affortryllelse, at den i sin deskriptivitet påstår at overflødiggøre den normative.

For forsøgsvis at male fanden på væggen: Den deskriptive affortryllelse kan på den ene side i sin udbredelse af ignoransen over for aktualiseringens mulighed tænkes at medføre en skødesløs omgang med idoler, med 
uhåndterlige aktualiseringer til følge, - nogle har måske set en sådan risiko i den på dette tidspunkt fremvoksende kunstreligion. På den anden side kan den indebære en total opgivelse af billedligheden, hvilket efterlader den menneskelige afmagt over for omstændigheden uforarbejdet. ${ }^{46}$ Uhåndterlig billedlighed og ubilledlig uhåndterlighed. Hvis et værk som Penthesilea på baggrund af en sådan dobbelt kriseerfaring er at opfatte som en efterlysning af myten - forstået som en sammenhæng af billedlighed og dogmatik - kan det ikke siges at være udtryk for irrationalistisk frådende sværmeri, men snarere for en afmytologiseringskritisk rationalitet.

Er det så muligt - skal det afslutningsvis spørges - i positiv forstand at tale om en remytologisering i Kleists drama, dvs. om en et forsøg på kunstnerisk fremstilling af en ny myte $?^{47}$ I så fald er det nok nødvendigt at bevæge sig ind på det kristologiske område, som ikke for alvor vil kunne behandles her, men alligevel ikke skal lades helt uberørt tilbage. Der optræder en række kristologiske motiver i teksten, ikke mindst i sidste scene umiddelbart efter at Penthesilea verbalt har spredt Tanaïs aske. Her erklærer hun: "Ich sage vom Gesetz der Frauen mich los,/ Und folge diesem Jüngling hier. $«^{48}$ Formuleringen henviser selvfølgelig til Achilles, men kunne nærmest være er citat fra Paulus med sin vægtning af Loven kontra Frelserens nærvær. Hermed antydes den idé, at selve behovet for Loven - her ikke jødernes antimytiske lov, men amazonernes mytiske - opløses i kraft af en guddommelig frelserskikkelse; forestillingen om et frelseshistorisk omslag fra den tilstand, hvor mytens fortælling om guderne må gøre den menneskelige lidelse håndterbar, bl.a. ved at formulere en guddommelig fordring af ofringer, til den situation, hvor myten lader guden selv tage menneskets lidelser på sig i en enkelt forløsende selvofring. Denne antydning af et kristent perspektiv hinsides tragikken kaster et nyt lys over Penthesileas sætten tænderne i sin elskede. For i den kristne kult - med dens ugentlige fortæring af Kristi legeme - kan vejen til genopstandelsen netop siges at gå igennem det totemistiske barbari.

46. Denne dobbelte skrækvision kan siges at komme til udtryk i et andet af periodens store forfatterskaber, nemlig E.T.A. Hoffmanns. På den ene side er Hoffmanns tekster fulde af dæmoniske inkarnationsscener: dukker, der bliver levende eller, som i Die Elexiere des Teufels, et maleri af Venus, der inkarnerer sig og vinder en uimodståelig erotisk magt over kunstneren. På den anden side bevirker den såkaldte "fantastiske tøven«, at den mytiske billeddannelse hele tiden bortrationaliseres eller -psykologiseres, dvs. at de manifestationer af overmenneskelige magter, som optræder, forklares som protagonistens hallucinationer og dermed som udtryk for et individuelt psykologisk problem. Denne diagnose indebærer principielt ideen om en mulig behandling af det psykologiske problem, - jf. Orestes' terapeutiske forløb - men en sådan overvindelse af omstændigheden synes hos Hoffmann sjældent at være for hånden, hvorfor den fantastiske tøvens opløsning af den mytiske billedlighed ender med blot at efterlade protagonist - og læser - i en mere uhåndgribelig afmagtssituation, udleveret til nye fantasmers fascinationskraft. 
Også i denne henseende kan Penthesilea betragtes som en genoptagelse af Bakkanterne, nemlig - hvor ankronistisk det end lyder - af visse kristologiske elementer: ${ }^{49} \mathrm{Guds}$ endnu ikke anerkendte søn kommer til byen, han pågribes af den lokale magthaver, og der følger en ironisk forhørsscene: »Du siger det selv«, svarede Jesus på spørgsmålet, om han var jødernes konge. Da Pentheus spørger ham: »hvad er din slægt?«(v. 447), svarer Dionysos: »Intet at prale af.«Et andet sted siger den tilfangetagne Dionysos som en anden Kristus: »Jeg lider ej, hvad ej jeg skal«(v. 501). Men ellers er det i denne sammenhæng netop afgørende, at det hos Euripides ikke som i Det ny Testamente er gudssønnen selv, men derimod de modvillige, Pentheus, Agaue og Kadmos, der ender med at lide. ${ }^{50}$ Hvor Bakkanterne således etablerer en distance imellem guden og volden, idet mytens dogmatiske stemme ovenfra dikterer sønderflåelsen af Pentheus som den tugtelse, der skal bringe orden i gudsdyrkelsen, opløser den kristne myte én gang for alle denne distance og lader guden selv ofres. Hvis resultatet af Penthesileas dialog med Bakkanterne, som jeg har argumenteret for, er, at Dionysos' dogmatiske distance omfortolkes til den dionysiske distanceløsheds brutalitet, er det måske ikke så underligt, at Kleists drama herefter vender interessen imod sammenhængen imellem Dionysos og Kristus, imellem sønderflåelsen og genopstandelsen, for deri måske alligevel at finde en form for guddommelig teleologi bag distanceløsheden.

47. Joachim Pfeiffer har i Kleist-Jahrbuch konfronteret den mytekritiske læsning af Penthesilea, repræsenteret ved Doris Claudia Borelbach, med remytologiseringslæsningen, repræsenteret ved Ennen. Pfeiffer ender med at konstatere begge de to vinklers utilstrækkelighed og foreslår på den baggrund den overraskende tredje mulighed at læse Penthesilea med blumenbergske briller. Han opfatter det således som et eksempel på mytens decentraliserende og dermed frigørende 'Spiel', når værket inddrager elementer af Dionysos-myten som en udfordring til amazonernes myte: „Gemmer der sig i dramaets dionysiske substrat ikke også et subversivt angreb på den overpræstelige dogmatik?«, "Mythos und Mythoskritik bei Heinrich von Kleist«, Kleist Jahrbuch (2000), p. 240-41. Det er for så vidt rigtigt, at Penthesileas dionysiske vanvid udgør en modmyte i forhold til amazonetraditionens myte, men for at kunne forklare denne modmytes funktion i Blumenbergs termer, dvs. som en distancering fra "virkelighedens absolutisme«, må man ignorere, at det dionysiske i Penthesilea netop indebærer fuldstændig distanceløshed og overgivelse til den »dæmoniske passivitet«. Frem for at dyrke en mytisk heterogenitet som protest imod amazonetraditionens dogmatiske enhed, demonstrerer dramaet med iscenesættelsen af sammenstødet imellem de to myter således selve utilstrækkeligheden i Blumenbergs modsætning imellem Mythos og Dogma. Mytens billedlighed har brug for Dogma for at kunne fungere som menneskelig bearbejdelse af omstændigheden.

48. Penthesilea, v. 3012 f. ["Jeg siger mig fri fra amazonernes lov og følger denne yngling»].

49. Se Jochen Hörisch: Brot und Wein, Frankfurt a.M. 1992, der bl.a. tematiserer Dionysosskikkelsens betydning for udformningen af Johannes-evangeliet og på den baggrund de tyske romantikeres interesse for netop sammenhængen imellem Kristus og Dionysos.

50. Som nævnt indgår det i myten om Dionysos, at han sønderflås af titanerne, en begivenhed, som mænaderne forholder sig mimetisk til. Dette motiv er selvfølgelig også en væsentlig faktor i identifikationen imellem Dionysos og Kristus. Men hos Euripides forskydes vægten altså netop fra denne ofrede til den ofrende gud. 